\title{
Attack of two new spider mites on sweet potato (Ipomoea batatas) in Diamantina, Minas Gerais State, Brazil
}

\author{
Soares, MA. ${ }^{a *}$, Castro, BMC. ${ }^{a}$, Andrade-Júnior, VC. ${ }^{a}$, Assis-Júnior, SL. ${ }^{a}$ and Pires, EM. ${ }^{b}$ \\ ${ }^{a}$ Universidade Federal dos Vales do Jequitinhonha e Mucuri - UFVJM, CEP 39100-000, Diamantina, MG, Brazil \\ ${ }^{b}$ Universidade Federal de Mato Grosso - UFMT, CEP 78550-000, Sinop, MT, Brazil \\ *e-mail: marcusasoares@yahoo.com.br
}

Received February 14, 2012 - Accepted April 2, 2012 - Distributed November 30, 2012

(With 1 figure)

Ipomoea batatas (L.) Lam. Convolvulaceae is a plant whose tubers are potentially used as food in underdeveloped countries (Mukhopadhyay et al., 2011). There are few reports on pests that attack sweet potato in Brazil. In addition, reports on mites that attack this plant are rare, referring only to the species Brevipalpus phoenicis (Geijskes, 1939) (Acari: Tenuipalpidae) (Flechtmann, 1987) and Tetranychus desertorum Banks, 1900 (Acari: Tetranychidae) (Mineiro et al., 2007).

The olericulture sector at Universidade Federal dos Vales do Jequitinhonha e Mucuri - UFVJM, in Diamantina, Minas Gerais state, Brazil, has a sweet potato germplasm bank, in pots, under greenhouse conditions. From August to November 2011, mites from the two species were observed attacking and causing severe damage and death in those plants (Figure 1). Infested leaves were taken out, packaged in plastic bags and later sent to taxonomist Dr. Gilberto José de Moraes from Escola Superior de Agricultura "Luiz de Queiroz" - ESALQ-USP, Piracicaba, São Paulo,

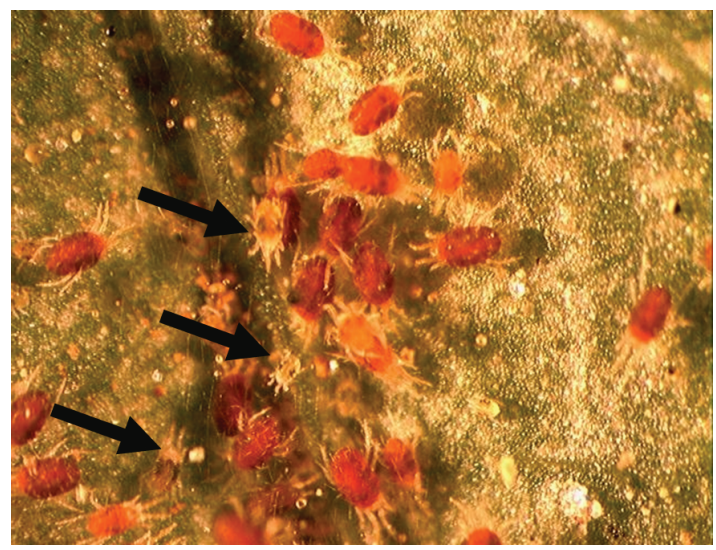

Figure 1. Tetranychus ludeni Zacher (red mite) infestation and Tetranychus urticae Koch (two-spotted spider mite - indicated by arrows) (Acari: Tetranychidae) in sweet potato (Ipomoea batatas L. Lam). Diamantina, Minas Gerais, Brazil, 2011.
Brazil. These mites were identified as Tetranychus ludeni Zacher, 1913 and Tetranychus urticae Koch, 1836 (Acari: Tetranychidae).

This is the first study reporting these species of Tetranychidae attacking the sweet potato. A recent revision related $T$. ludeni to the host plants Citrullus lanatus (Thunb.) Cucurbitaceae; Pelargonium hortorum L.H. Bailey Geraniaceae (geranium); Prunus domestica L. Rosaceae (plumb) and Citrus limonia L. Rutaceae (mandarin-lime). Tetranychus urticae was associated with the species Ambrosia polystachya D.C. Asteracea (ragweed); Parthenium sp. Asteracea (parthenium); Pyrostegia venusta Miers Bignoniaceae (flame vine); Phaseolus lunatus L. Fabaceae (lima beans); Macroptilium atropurpureum (L.) Fabaceae (siratro); Passiflora edulis Sims Passifloraceae (yellow passion fruit); Triticum aestivum L. Poaceae (wheat); Alpinia purpurata K. Schum Zingiberaceae (alpinia) and Lantana camara L. Verbenaceae (wild sage) (Mendonça et al., 2011). The species T. ludeni and T. urticae occur together and have potential to cause severe damage and death to sweet potato plants cultivated in Brazil. They should thus be considered in programmes of integrated pest management - IPM - for this crop.

\section{References}

FLECHTMANN, CHW., 1987. Sobre uma pequena coleção de ácaros (Arthropoda, Acari) do Território Federal de Fernando de Noronha, Brasil. Anais da ESALQ, vol. 44, p. 1643-1647.

MENDONÇA, RS., NAVIA, D., DINIZ, IR. and FLECHTIMANN, CHW., 2011. South American spider mites: New hosts and localities. Journal of Insect Science, vol. 11, no. 121, p. 1-17. PMid: 22224405

MINEIRO, JLC., MONTES, SMNM. and RAGA, A., 2007. Primeiro registro de Tetranychus desertorum (banks) (Acari: Tetranychidae) em batata-doce (Ipomoea batatas L.) em Presidente Prudente, SP. O Biológico, vol. 69, no. 2, p. 113-198.

MUKHOPADHYAY, SK., CHATTOPADHYAY, A., CHAKRABORTY, I. and BHATTACHARYA, I., 2011. Crops that feed the world 5. Sweetpotato. Sweetpotatoes for income and food security. Food Security, vol. 3, no. 3, p. 283-305. http:// dx.doi.org/10.1007/s12571-011-0134-3 
